\title{
Quantification of Airborne Inoculum as an Aid in the Management of Leaf Blight of Onion Caused by Botrytis squamosa
}

O. Carisse, HRDC, Agriculture and Agri-Food Canada, St-Jean-sur-Richelieu, Québec, J3B 3E6, Canada; H. A. McCartney, Plant Pathogens Interactions, Rothamsted Research, Harpenden, Hertfordshire, AL5 2JQ, UK; and J. A. Gagnon and L. Brodeur, Prisme Consortium, Sherrington, Québec, J0L 2N0, Canada

\begin{abstract}
Carisse, O., McCartney, H. A., Gagnon, J. A., and Brodeur, L. 2005. Quantification of airborne inoculum as an aid in the management of leaf blight of onion caused by Botrytis squamosa. Plant Dis. 89:726-733.

Botrytis leaf blight, caused by Botrytis squamosa, is a common and frequently damaging disease of onion crops, but the severity of epidemics varies widely from year to year. The disease is initiated and spread by airborne conidia. The relationship between airborne conidium concentration (ACC) and lesion development was studied in the field. A linear relationship was found between ACC and number of lesions per leaf: ACC values of 10 to 15 and 25 to 35 conidia $\mathrm{m}^{-3}$ were associated with 1 and 2.5 lesions per leaf, respectively. In 2000 and 2001, at three sites, four different criteria were used to start a fungicide spray program and their effect on epidemic development was compared with that of a grower's conventional schedule. The criteria were: at the fourth-true-leaf growth stage; according to an inoculum production index; when the ACC reached 10 to 15 conidia $\mathrm{m}^{-3}$; and when the ACC reached 25 to 35 conidia $\mathrm{m}^{-3}$. A nonsprayed control plot was included in the trial. Fungicide programs started when the ACC reached 10 to 15 conidia $\mathrm{m}^{-3}$ were as effective as the conventional program, but used fewer sprays. A fungicide spray program based on measurements of ACC and disease severity was evaluated in 2002 and 2003 in five and three commercial onion fields, respectively. At each site, half of the field was sprayed according to the grower's schedule and, in the other half, fungicide sprays were initiated when a threshold of 10 to 15 conidia $\mathrm{m}^{-3}$ or five lesions on the lower leaf (whichever came first) was reached. Overall, the number of fungicide applications was reduced by 75 and 56\% in 2002 and 2003, respectively, without causing significant yield reduction. In both years, the reduction in number of fungicide applications was due mainly to the delay in initiation of the fungicide program.
\end{abstract}

Additional keywords: disease management

Botrytis leaf blight, caused by Botrytis squamosa J. C. Walker, is a serious disease of onion (Allium cepa L.) and has been reported in onion-producing areas of Asia, Europe, and South and North America $(7,13,17,25)$. In the muck soils of eastern Canada, New York, and Michigan, the disease is endemic and destructive epidemics can develop during warm and moist summers, causing reduction in bulb size and consequent economic loss $(1,2,26)$. Epidemics are initiated by airborne conidia produced by sclerotia that overwinter in soil, on onion debris, or on onions in cull piles $(8,9)$. Conidia are produced at temperatures ranging from 3 to $27^{\circ} \mathrm{C}$ (optimum $9^{\circ} \mathrm{C}$ ) (18). Initial symp-

Corresponding author: O. Carisse

E-mail: carisseo@agr.gc.ca

This work was financially supported by a Matching Investment Initiative between Agriculture and AgriFood Canada, the Prisme Consortium, and la Fédération des Producteurs Maraîchers du Québec.

Accepted for publication 2 March 2005.

DOI: 10.1094/PD-89-0726

(C) 2005 The American Phytopathological Society become more susceptible to infection and secondary spread can lead to leaf blight (upper leaves covered with white necrotic lesions) after 5 to 12 days. Secondary spread is caused by airborne conidia produced on necrotic tissues, usually during the night, when the leaves are wet and the temperature is between 8 and $22^{\circ} \mathrm{C}$ $(21,23)$.

There appears to be little resistance to B. squamosa infection in commercial onion cultivars (6); consequently, management of Botrytis leaf blight is achieved mainly with fungicides. In Eastern Canada, growers typically apply a preventive fungicide such as Dithane DG (a.i. mancozeb) at 7- to 10-day intervals starting in mid-June for onion sown midMay, or when the onions are at the fourthleaf growth stage. This results in 6 to 10 fungicide sprays per season (5). The time of disease onset and disease severity vary greatly from year to year and, in some years, control measures are not needed or could be delayed. Prediction schemes have been developed to improve disease control during periods of high disease pressure and to reduce fungicide use when disease risk is low $(15,19,22,28)$. Forecasting systems have been developed to define the start of fungicide programs toms are leaf spots, 1- to 5-mm-long lesions, generally surrounded by a greenish-white halo. As leaves age, they

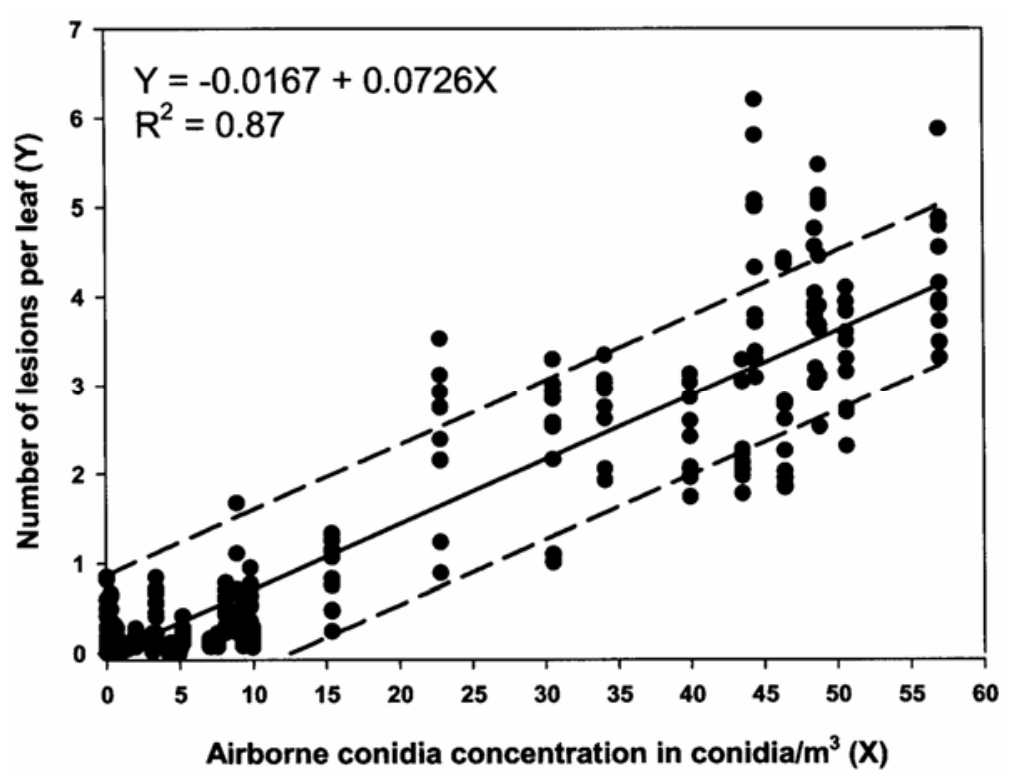

Fig. 1. Number of lesions of Botrytis squamosa on onion leaves and airborne conidium concentration observed in 1999 and 2000. The solid line represents the linear regression through the measured points and the dashed lines the upper and lower $95 \%$ confidence limits. 
$(19,22)$ or to time intervals between fungicide sprays throughout the season $(15,28)$. Shoemaker and Lorbeer (19) proposed using "critical disease levels" (CDLs) to initiate fungicide programs. However, the use of CDLs requires intensive biological monitoring; thus, sequential sampling plans have been developed to increase the efficiency of sampling $(2,26)$. In Ontario, Canada, the spray threshold is set at one lesion per leaf based on observation of the three oldest green leaves $(80 \%$ green tissue) on 50 to 100 plants across the whole field area. In the organic soil area of southwestern Montreal, the CDL is 1 lesion per leaf for EBDC fungicides, such as Dithane, and 5 to 10 for fungicides such as Bravo (a.i. chlorothalonil) or Rovral (iprodione).

Airborne conidia of $B$. squamosa drive epidemics of Botrytis leaf blight $(12,15,23)$. Depending on the prevailing weather conditions, the amounts of conidia produced above the onion canopy vary greatly from year to year $(15,23)$. Consequently, three leaf blight prediction systems have been developed that use an estimation of sporulation potential, usually based on weather information $(15,22,26)$. However, direct monitoring of the concentration of airborne conidia has never been used as part of a Botrytis leaf blight control program. Monitoring airborne inoculum could help to determine the need for fungicide applications as well as the scouting efforts required to efficiently monitor disease in crops on a farm basis. This approach was studied for management of late blight of tomato caused by Phytophthora infestans. Bugiani et al. (3) showed that airborne sporangia concentration monitored at several sites increased rapidly 1 to
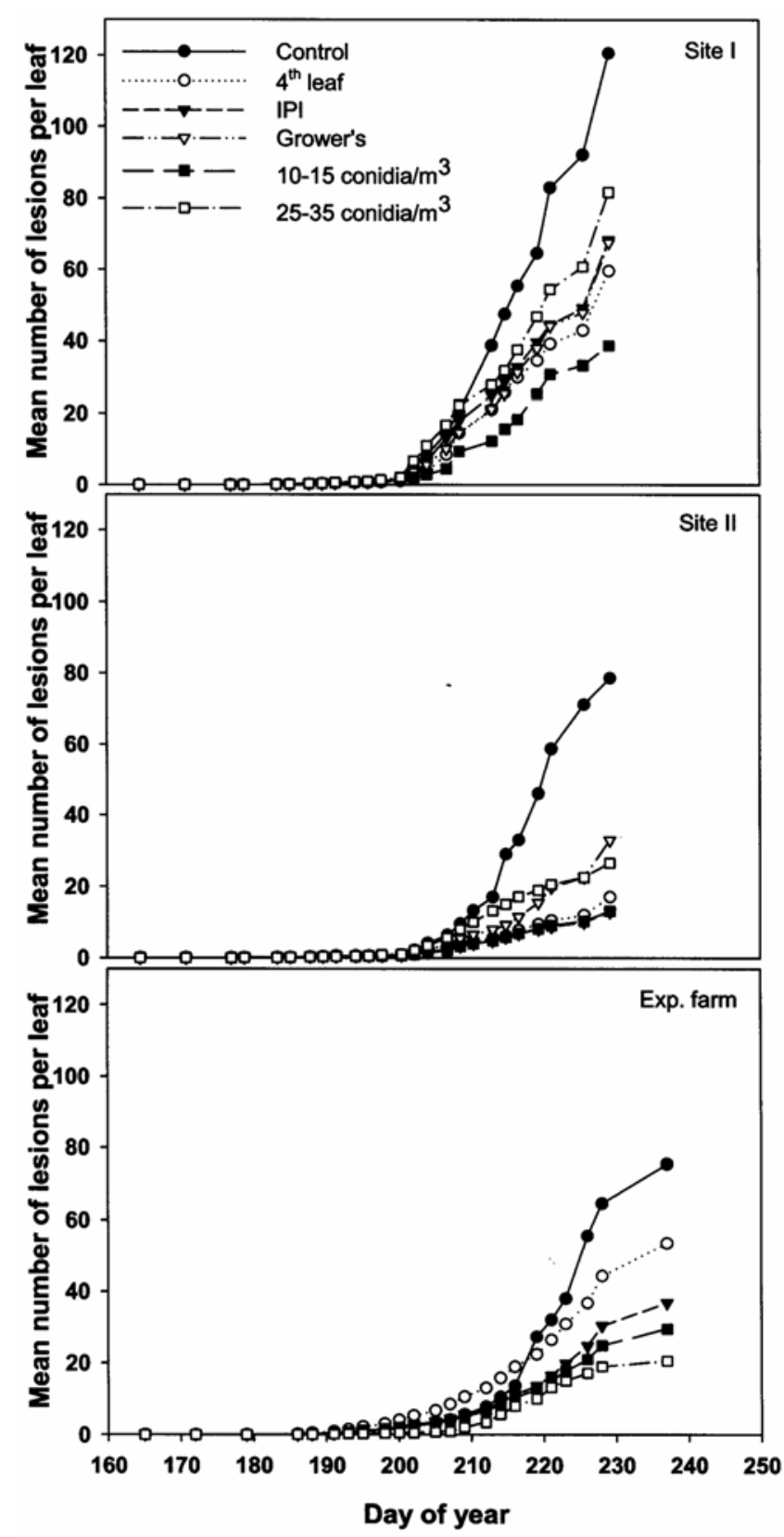

Fig. 2. Progression of Botrytis leaf blight epidemics (disease severity) observed in 2000 in onion plots at three different sites. The spray program was started according to different criteria: Control $=$ nonsprayed; 4 th leaf $=$ spray started at the fourth-leaf growth stage; IPI $=$ the inoculum production index; Grower's = grower's conventional spray program; 10 to 15 conidia $=$ when Botrytis squamosa conidia concentrations reached 10 to 15 conidia $\mathrm{m}^{-3} ; 25$ to 35 conidia $=$ when $B$. squamosa conidia concentrations reached 25 to 35 conidia $\mathrm{m}^{-3}$.

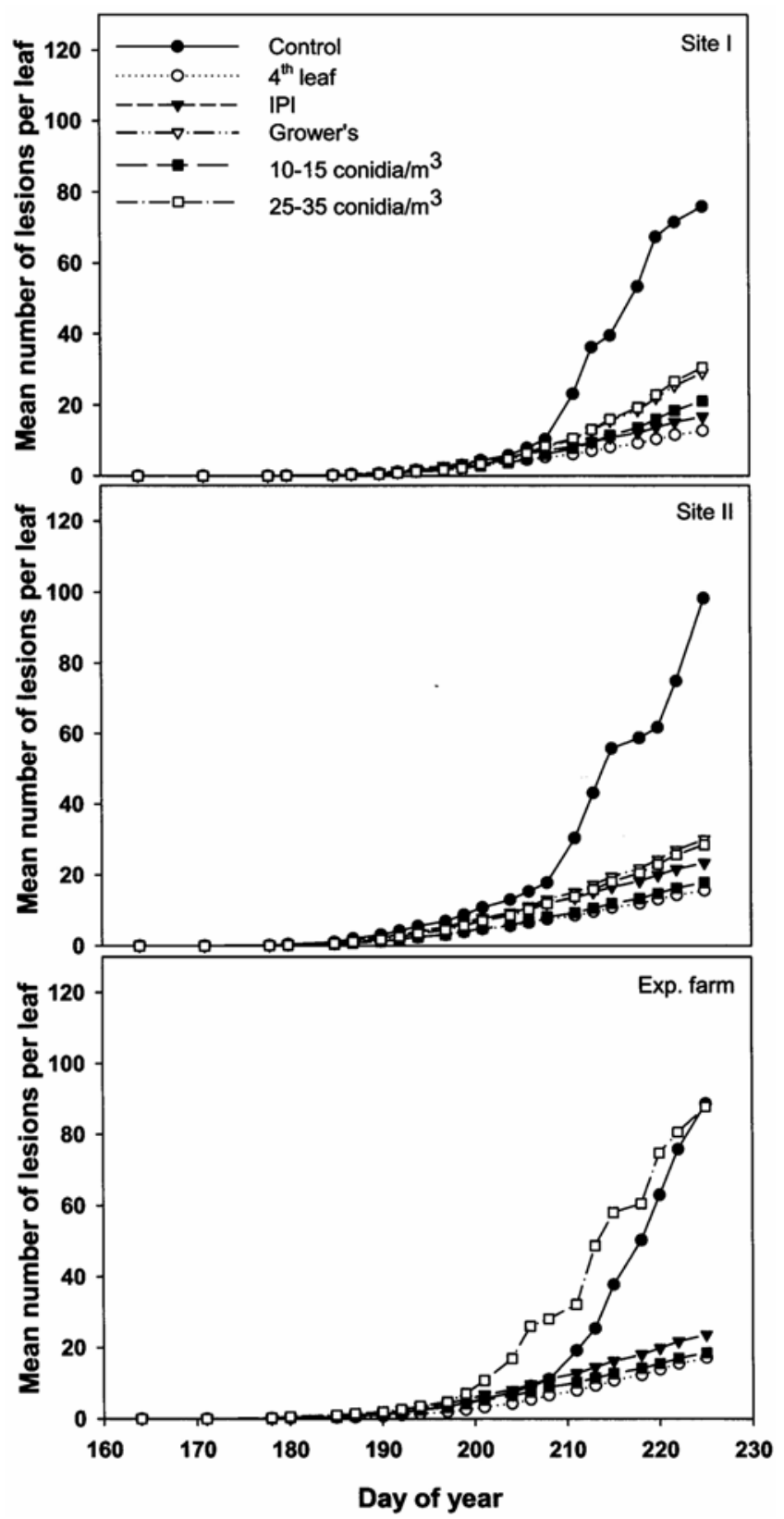

Fig. 3. Progression of Botrytis leaf blight epidemic (disease severity) observed in 2001 in onion plots at three different sites. The spray program was started according to different criteria: Control = nonsprayed; 4th leaf $=$ spray started at the fourth-leaf growth stage; IPI = the inoculum production index; Grower's = grower's conventional spray program; 10 to 15 conidia $=$ when Botrytis squamosa conidia concentrations reached 10 to 15 conidia $\mathrm{m}^{-3} ; 25$ to 35 conidia $=$ when $B$. squamosa conidia concentrations reached 25 to 35 conidia $\mathrm{m}^{-3}$. 
2 weeks before late blight onset. Consequently, they proposed using information on airborne sporangia concentration to time initiation of fungicide programs. Therefore, the aims of this study were to establish thresholds of concentration of airborne conidia at which a fungicide program should be initiated; evaluate the efficacy of spray programs initiated based on measured airborne conidia concentrations; and evaluate, under commercial conditions, a fungicide spray program based on airborne conidium concentration (ACC) and disease evaluation for the control of Botrytis leaf blight in onion crops.

\section{MATERIALS AND METHODS}

Relationship between ACC and number of lesions per leaf. The experiments were done at the Agriculture and AgriFood Canada Experimental Farm at SteClotilde, Quebec. On 7 May 1999 and 10 June 2000 , three plots of 10 by $10 \mathrm{~m}$ were established by sowing onion (cv. Tribute)

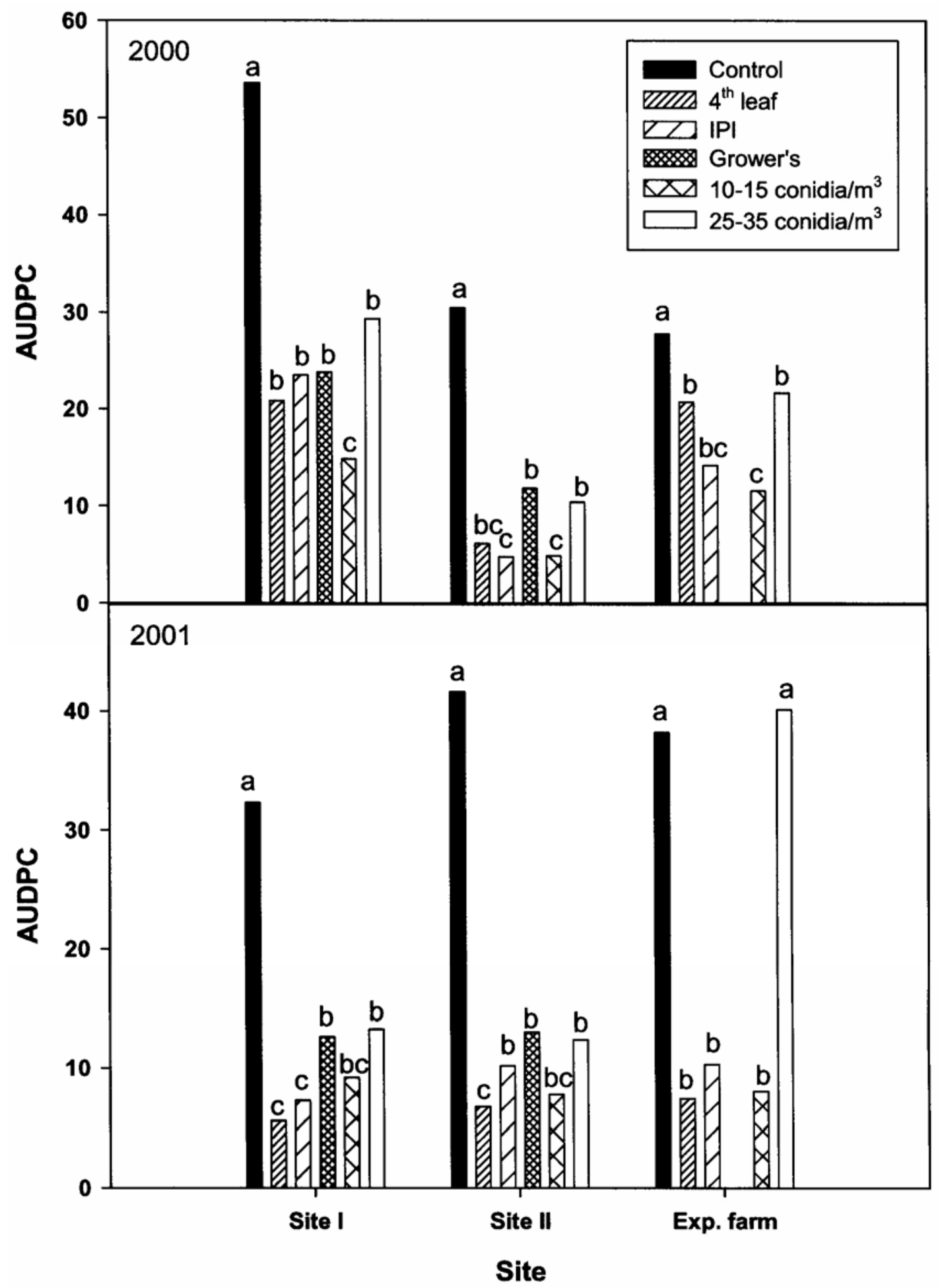

Fig. 4. Area under the disease progress curve (AUDPC) for 2000 and 2001 in onion plots where the spray program was stared using different criteria. Values of bars with the same letters are not significantly different according to the least significant difference test $(P=0.05)$. Control $=$ nonsprayed; 4 th leaf $=$ spray started at the fourth-leaf growth stage; IPI = the inoculum production index; Grower's $=$ grower's conventional spray program; 10 to 15 conidia $=$ when Botrytis squamosa conidia concentrations reached 10 to 15 conidia $\mathrm{m}^{-3} ; 25$ to 35 conidia = when B. squamosa conidia concentrations reached 25 to 35 conidia $\mathrm{m}^{-3}$. 
at a rate of $30 \mathrm{seed} / \mathrm{m}$ of row with a row spacing of $0.36 \mathrm{~m}$. The plots were not treated with insecticides unless necessary and weeding was done by hand four times during the course of the experiments (5). ACC of B. squamosa conidia was measured in the center of each plot using rotating-arm impaction spore samplers (Rotorod type) placed at 10 to $15 \mathrm{~cm}$ above the canopy. One sampler was used per plot, and ran from 10:00 to 12:00, two to three times per week on Mondays, Wednesdays, and Fridays. This sampling period was chosen because $B$. squamosa conidia concentrations usually peak between 9:00 and 12:00 (21,23). Sampling time was restricted to $2 \mathrm{~h}$ to reduce the accumulation of dust on the sampling surface. Each sampler consisted of two vertical arms (1.65- $\mathrm{mm}^{2}$ cross-section, $20 \mathrm{~mm}$ long) separated by $83 \mathrm{~mm}$ and rotated at 2,400 rpm. Airborne particles were impacted onto the leading edges of the rotation rods. The effective sampling rate was 20.65 liters of air/min. After exposure, the number of conidia per rod was counted under a microscope at $\times 250$ and the counts were transformed to concentrations of conidia per cubic meter (number of spores per rod $\times 1,000$ liters $\left.\mathrm{m}^{-3}\right) /(20.65$ liters $/ \mathrm{min} \operatorname{rod} \times$ $60 \mathrm{~min} / \mathrm{h} \times 2 \mathrm{~h}$ ). On each sampling day, the number of lesions per leaf was counted on 10 plants per plot selected at random. The plots were arranged in a randomized design and each plot was separated from its nearest neighbor by at least $200 \mathrm{~m}$.

Evaluation of inoculum thresholds for the initiation of fungicide spray program. The experiments were done in 2000 and 2001 at the Agriculture and Agri-Food Canada Experimental Farm at Ste-Clotilde, Quebec and in two commercial onion fields at Sherrington (sites I and II), about $50 \mathrm{~km}$ southwest of Montreal, in the organic soil area. At each site, 18 plots (20 by $30 \mathrm{~m}$ ) were sown with onion (cv. Tribute) at a rate of $30 \mathrm{seed} / \mathrm{m}$ of row and row spacing of $0.36 \mathrm{~m}$. Each plot was separated from the others by at least $50 \mathrm{~m}$. The plots were sown on 21 May, 17 May, and 1 June 2000 and on 2 May, 5 May, and 30 April 2001 at site I, site II, and the experimental farm, respectively. Five criteria for starting the spray program were tested at each site. The spray program was initiated (i) at the fourth-leaf growth stage, (ii) when the ACC reached 10 to 15 conidia $\mathrm{m}^{-3}$ of air, (iii) when the ACC reached 25 to 35 conidia $\mathrm{m}^{-3}$ of air, (iv) according to the grower's schedule (not used at the experimental farm), and (v) based on an inoculum production index (IPI). The IPI was calculated each day based on temperature and relative humidity (27). The IPI values varied from 0 to 25 and represented the absence (IPI $=0$ ) or presence of significant sporulation. A threshold value of IPI $=7$ was used to initiate fungicide program.

Nonsprayed plots served as controls. Each treatment, including controls, was replicated three times in a randomized complete block design. The spray program consisted of the application of Dithane DG (a.i. mancozeb 75\%; Dow AgroSciences, Indianapolis, IN) at $2.4 \mathrm{~kg} / \mathrm{ha}$ every 7 days. At the experimental farm, 50 sclerotia of B. squamosa were spread randomly on the soil surface during the first week of June to ensure that inoculum was present. Sclerotia were produced on autoclaved onion leaves incubated at $18^{\circ} \mathrm{C}$ in an incubator with a 12-h photoperiod. Sites I and II relied on natural inoculum. All cultural practices and spray operations were done by the growers according to standard commercial practices (5) A rotating-arm spore sampler (as described previously) was placed in the center of each plot, and ran from 10:00 to 12:00, two to three times per week (Mondays, Wednesdays, and Fridays). An additional sampler was operated $5 \mathrm{~m}$ upwind of each plot to measure incoming inoculum of $B$. squamosa. $B$. squamosa conidia concentrations were calculated from the spore samplers as described above. On each sampling day, the number of lesions per leaf was counted on 10 plants per plot selected at random. At harvest, all onions on $1 \mathrm{~m}$ of row selected at random within each plot but avoiding the border rows were sized and weighed; three replicate samples were taken per plot. Yield was expressed as the number of marketable onions per meter of row.

Evaluation of a spray program based on airborne inoculum concentration. The experiments were done in commercial onion fields ( 200 by $400 \mathrm{~m}$ ) in the organic soil area southwest of Montreal, Quebec. Five fields were used in 2002 and three in 2003. In both years, the fields were sown in May with susceptible onion cultivars (Copra, Flagship, BGS-12, Fortress, Millennium, and Frontier). In all fields, onions

Table 1. Number of fungicide sprays applied to onion plots in 2000 and 2001 in response to different criteria used to initiate the fungicide program and the resulting yield

\begin{tabular}{|c|c|c|c|c|c|c|}
\hline \multirow[b]{2}{*}{ Year, initiation $^{\mathrm{z}}$} & \multicolumn{3}{|c|}{ Number of sprays } & \multicolumn{3}{|c|}{ Yield (onions $\mathrm{m}^{-1}$ of row) ${ }^{\mathrm{y}}$} \\
\hline & Exp. farm & Site I & Site II & Exp. farm & Site I & Site II \\
\hline \multicolumn{7}{|l|}{2000} \\
\hline Control & 0 & 0 & 0 & $8.00 \mathrm{~b}$ & $4.67 \mathrm{c}$ & $7.33 \mathrm{c}$ \\
\hline Fourth leaf & 8 & 8 & 8 & $13.33 \mathrm{a}$ & $13.33 \mathrm{a}$ & $15.67 \mathrm{ab}$ \\
\hline IPI & 7 & 7 & 7 & $16.00 \mathrm{a}$ & $12.00 \mathrm{ab}$ & $17.33 \mathrm{~b}$ \\
\hline Grower's & $\ldots$ & 10 & 10 & & $10.67 \mathrm{ab}$ & $15.00 \mathrm{ab}$ \\
\hline 10 to 15 conidia & 6 & 6 & 6 & $16.67 \mathrm{a}$ & $14.00 \mathrm{a}$ & $17.33 \mathrm{a}$ \\
\hline 25 to 35 conidia & 3 & 4 & 4 & $12.33 \mathrm{ab}$ & $8.00 \mathrm{bc}$ & $12.00 \mathrm{~b}$ \\
\hline \multicolumn{7}{|l|}{2001} \\
\hline Control & 0 & 0 & 0 & $8.67 \mathrm{~b}$ & $6.67 \mathrm{a}$ & $7.33 \mathrm{c}$ \\
\hline Fourth leaf & 7 & 8 & 8 & $21.67 \mathrm{a}$ & $18.00 \mathrm{a}$ & $20.67 \mathrm{ab}$ \\
\hline IPI & 5 & 4 & 4 & $19.33 \mathrm{a}$ & $15.67 \mathrm{ab}$ & $21.67 \mathrm{a}$ \\
\hline Grower's & . & 9 & 9 & & $11.67 \mathrm{bc}$ & $18.33 \mathrm{ab}$ \\
\hline 10 to 15 conidia & 5 & 4 & 4 & $20.33 \mathrm{a}$ & $13.67 \mathrm{bc}$ & $21.67 \mathrm{a}$ \\
\hline 25 to 35 conidia & 2 & 3 & 3 & $9.00 \mathrm{~b}$ & $10.00 \mathrm{dc}$ & $15.00 \mathrm{~b}$ \\
\hline
\end{tabular}

${ }^{y}$ Values with the same letters are not significantly different according to the least significant difference test $(P=0.05)$.

${ }^{\mathrm{z}}$ Initiation of fungicide sprays. Control $=$ nonsprayed; Fourth leaf $=$ sprays started at the fourth-leaf growth stage; IPI = based on the inoculum production index; Grower's = grower's conventional spray program; 10 to 15 conidia = when Botrytis squamosa conidia concentrations reached between 10 and 15 conidia $\mathrm{m}^{-3}$; and 25 to 35 conidia = when B. squamosa conidia concentrations reached between 25 and 35 conidia $\mathrm{m}^{-3}$. row spacing of $0.36 \mathrm{~m}$. Each field was conventional schedule. The fungicide program used by the growers was initiated at the CDL of one lesion per leaf per plant, a sample of 10 plants per plot. when the conidia concentration reached 10 to 15 conidia $\mathrm{m}^{-3}$ or when an average of five lesions on the lowest leaves was sample of 10 plants (10 lower leaves examined). The lowest leaf was the oldest leaf with at least $80 \%$ of its surface still green. The fungicides used were Dithane DG alone or mixed with Rovral (iprodione, gle Park, NC). The choice of fungicide was made by the growers; however, in general, they used Dithane alone under low disease Rovral under high disease pressure. The same approach was used in the experimenplots. In the experimental plots, two above the canopy in the first and second third of the field (lengthwise) and in the middle of each plot (along the width). The mplers ran for $2 \mathrm{~h}$ from 10:00 to 12:00, days, and Fridays). B squamosa conidia concentrations were assessed as described previously. Disease severity was evaluated on each sampling day by counting the leaves (oldest but still $80 \%$ green) of 10 plants per section of each field selected at random. At harvest, marketable yield was estimated as described previously. Late fungicide sprays were applied to prevent the development of storage diseases (6). were sown at a rate of $30 \mathrm{seed} / \mathrm{m}$ with a plot was sprayed according to the grower's pressure, estimated based on the number of 
Data analysis. The relationship between ACC and number of lesions per leaf (LL) on individual plants was investigated only for those data sets with less than 20 LL. Even though data were collected during the course of the entire seasons, we were interested only in the ACC-LL relationship when the number of LL was low. Linear regression analysis was used to determine the relationship between ACC and LL. To evaluate the effect of fungicide program, the area under the disease progress curve (AUDPC) was calculated as:

$$
\text { AUDPC } \left.=\sum_{i=1}^{n}\left\{\left(y_{i}+y_{i-1}\right) / 2\right] *\left(t_{i}-t_{i-1}\right)\right\}
$$

in which $n$ is the number of assessment times, $y$ is the mean number of LL per plant per plot, and $t$ is time in days. Analysis was done separately for each site and each year. Analysis of variance (ANOVA) was used to test the effects of spray programs on AUDPC and on onion yields. Multiple comparison tests (least significant difference [LSD]) were used to detect significant differences among means (AUDPC or yield) at $P=0.05$ (20). Statistical analyses were conducted using the
SAS software program (version 8.0; SAS Institute Inc., Cary, NC).

\section{RESULTS}

Relationship between ACC and number of LL. There was a linear relationship between the ACC and the number of LL (Fig. 1). The coefficient of determination $\left(R^{2}\right)$ was 0.87 and the rate parameter was significantly different than $0(P<0.0001)$ (Fig. 1). Figure 1 was used to determine the two concentration thresholds used to start the spray program. These were chosen as 10 to 15 and 25 to 35 conidia $\mathrm{m}^{-3}$,

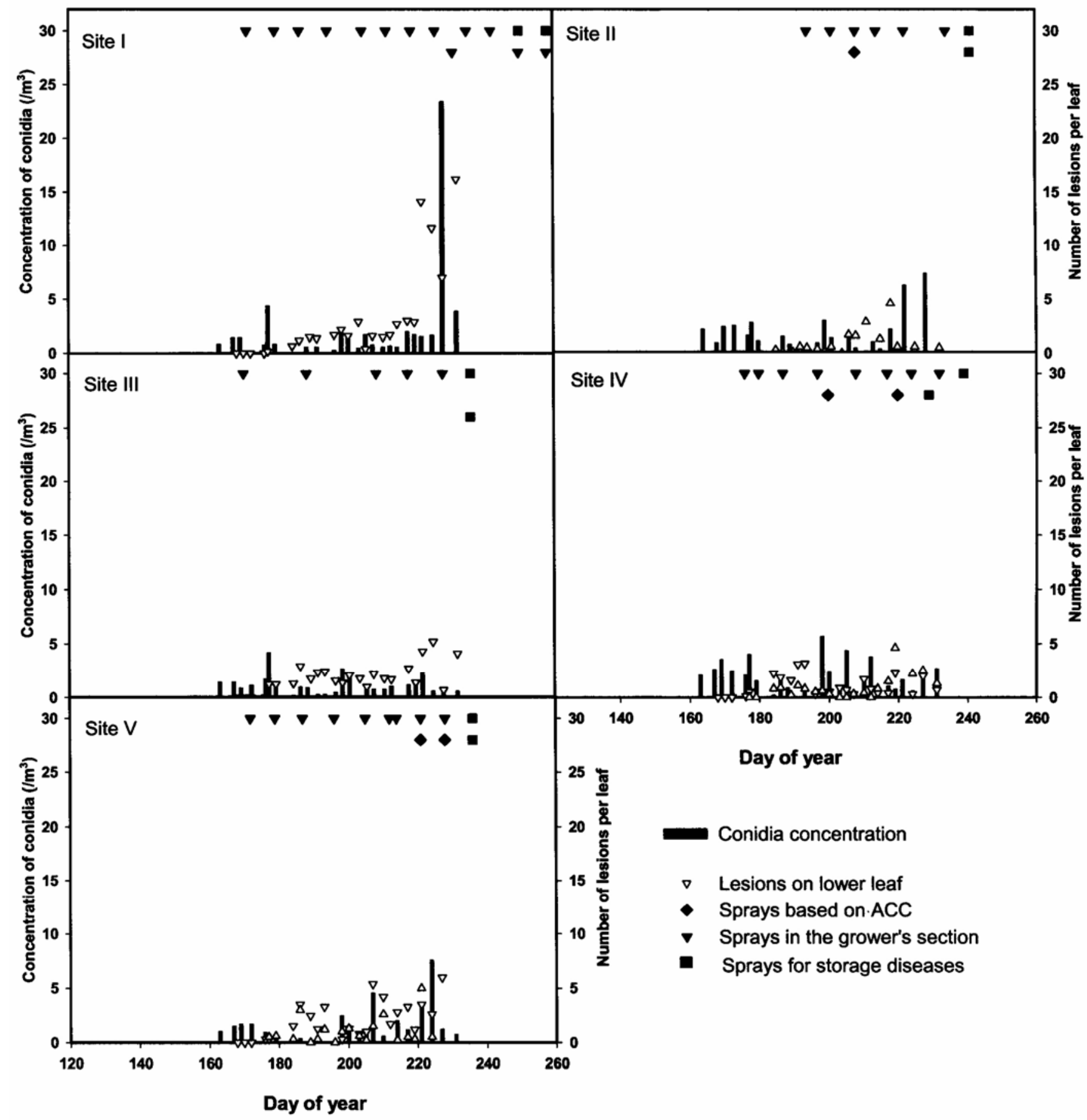

Fig. 5. Airborne conidium concentration (ACC) in conidia $\mathrm{m}^{-3}$ (bars) and number of lesions of Botrytis squamosa on the lower onion leaves (symbols) observed in 2002. Dark triangles represent when fungicide was sprayed according to the grower's schedule and dark diamonds when the sprays were applied when the airborne conidium concentration reached 10 to 15 conidia $\mathrm{m}^{-3}$. The sprays applied after day 230 were to control postharvest (storage) diseases. 
corresponding to 1 and $2.5 \mathrm{LL}$, respectively. The relationship between ACC and the number of LL and between ACC and the number of lesions on the lowest leaf was similar (data not shown).

Evaluation of inoculum thresholds for the initiation of fungicide spray program. For both years and all plots, incoming inoculum represented less than $8 \%$ of the inoculum monitored during the season. Incoming inoculum was detected only at the end of the season; consequently, it was assumed that inoculum measured within each plot was representative of airborne inoculum in that plot. The shapes of disease progress curves were similar regardless of the criteria used to start the fungicide program, and more disease developed in the nonsprayed treatments (Figs. 2 and 3 ). For both years and all sites, the AUDPC was significantly higher in nonsprayed treatments than any of the sprayed treatments, except for the treatment at the experimental farm in 2001, where the spray program was started when conidia concentrations reached 25 to 35 conidia $\mathrm{m}^{-3}$, which was not significantly different than the AUDPC in control treatments (Fig. 4). In 2000, the AUDPC in treatments where the fungicide program was initiated based on a concentration of conidia of 10 to 15 conidia $\mathrm{m}^{-3}$ was significantly lower than in treatments sprayed according to the grower's schedule (Fig. 4). However, at all sites, the AUDPC in treatments where the fungicide program was initiated at a concentration of conidia of 25 to 35 conidia $\mathrm{m}^{-3}$ was not significant different than the AUDPC from treatments sprayed according to the grower's schedule, the IPI, or when the spray program was initiated at the fourth-leaf growth stage (Fig. 4). In 2001, the AUDPC was significantly lower for treatments where the fungicide program was started at the fourth-leaf growth stage (fourth true leaf) compared with the AUDPC for treatments sprayed according to the grower's schedule (Fig. 4.). In both years, the disease levels were among the lowest when a threshold of 10 to 15 conidia $\mathrm{m}^{-3}$ was used to initiate the fungicide program and among the highest for sprayed treatments with the threshold of 25 to 35 conidia $\mathrm{m}^{-3}$, suggesting that a threshold of 25 to 35 conidia $\mathrm{m}^{-3}$ was too high and should not be used to initiate a fungicide program. For both years and all sites, initiation of fungicide sprays based on IPI and ACC of 10 to 15 conidia $\mathrm{m}^{-3}$ resulted in a lower number of sprays being ap- plied (Table 1). In both years, the marketable yield in sprayed treatments was significantly higher $(P=0.01,0.06$, $0.003,0.0001,0.0007$, and 0.0004 for the experimental farm, site I, and site II in 2000 and 2001, respectively) than in the nonsprayed treatments (control), with the exception of treatments sprayed based on a threshold of 25 to 35 conidia $\mathrm{m}^{-3}$ (Table 1).

Evaluation of a spray program based on ACC. Epidemics of Botrytis leaf blight were less severe in 2002 than in 2003 (Figs. 5 and 6). In 2002, ACC were below the threshold of 10 to 15 conidia $\mathrm{m}^{-3}$ for most of the growing season (Fig. 5). Similarly, the number of lesions on the lower leaf was below the threshold of 5 and 10 lesions, except toward the end of the season at site I. Consequently, using an inoculum concentration threshold of 10 to 15 conidia $\mathrm{m}^{-3}$ to start the spray program (ACC schedule) resulted in the application of only a few fungicide sprays in the experimental portion of the fields (Table 2) and, toward the end of the season, the sprays were applied mainly to prevent storage diseases. Overall for all sites, 11 sprays were applied to the experimental plots (ACC schedule) compared with 44

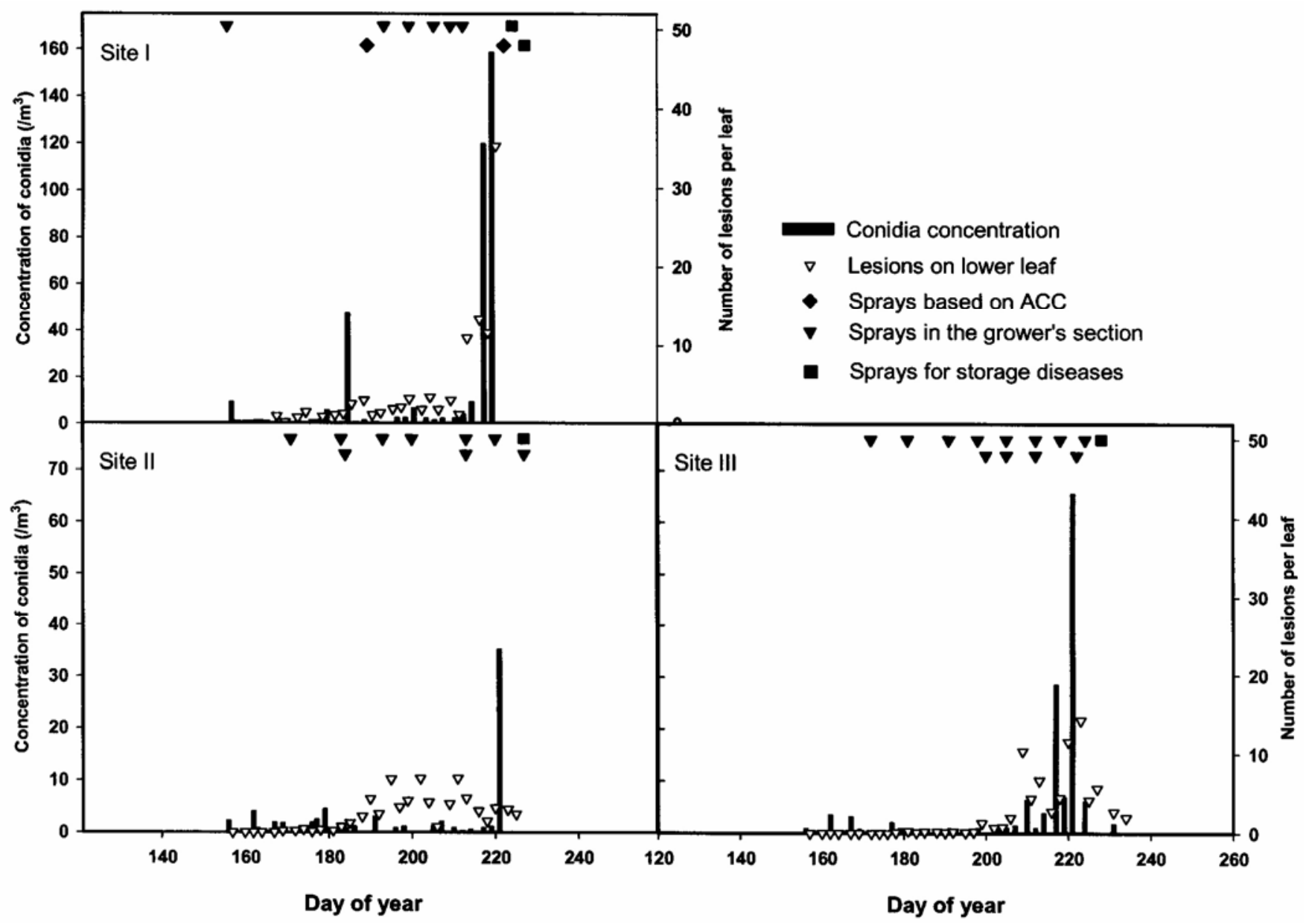

Fig. 6. Airborne conidium concentration (ACC) in conidia $\mathrm{m}^{-3}$ (bars) and number of lesions of Botrytis squamosa on the lower onion leaves (symbols) observed in 2003. Dark triangles represent when fungicide was sprayed according to the grower's schedule and dark diamonds when the sprays were applied when the airborne conidium concentration reached 10 to 15 conidia $\mathrm{m}^{-3}$. 
Table 2. Number of fungicide sprays and the amount of fungicide used in 2002 and 2003 in commercial onion plots ${ }^{\mathrm{y}}$

\begin{tabular}{|c|c|c|c|c|}
\hline \multirow[b]{2}{*}{ Year, site } & \multicolumn{2}{|c|}{ Number of fungicide sprays } & \multicolumn{2}{|c|}{ Quantity of fungicide, kg/ha (liters/ha) ${ }^{\mathrm{z}}$} \\
\hline & $\mathrm{ACC}$ & Grower's & $\mathrm{ACC}$ & Grower's \\
\hline \multicolumn{5}{|l|}{2002} \\
\hline I & 3 & 12 & 7.55 & 24.5 \\
\hline II & 2 & 7 & 1.50 & 5.10 \\
\hline III & 1 & 6 & 2.20 & 12.70 \\
\hline IV & 2 & 9 & 1.50 & 20.20 \\
\hline $\mathrm{V}$ & 3 & 10 & 7.00 & 22.70 \\
\hline \multicolumn{5}{|l|}{2003} \\
\hline I & 3 & 7 & 3.75 & 12.25 \\
\hline II & 3 & 7 & $5.25(3.00)$ & 15.75 \\
\hline III & 4 & 9 & $3.00(7.00)$ & $10.70(12.25)$ \\
\hline
\end{tabular}

y $\mathrm{ACC}=$ airborne conidium concentration; spray program started when ACC reached 10 to 15 conidia $\mathrm{m}^{-3}$ or five lesions on the lower leaf (whichever came first). Grower's = sprayed according to the grower's conventional schedule. The type of fungicide used in the ACC plots was determined by the observed disease level.

${ }^{\mathrm{z}}$ Fungicides used were Dithane in $\mathrm{kg} / \mathrm{ha}$ and Rovral in liters/ha.

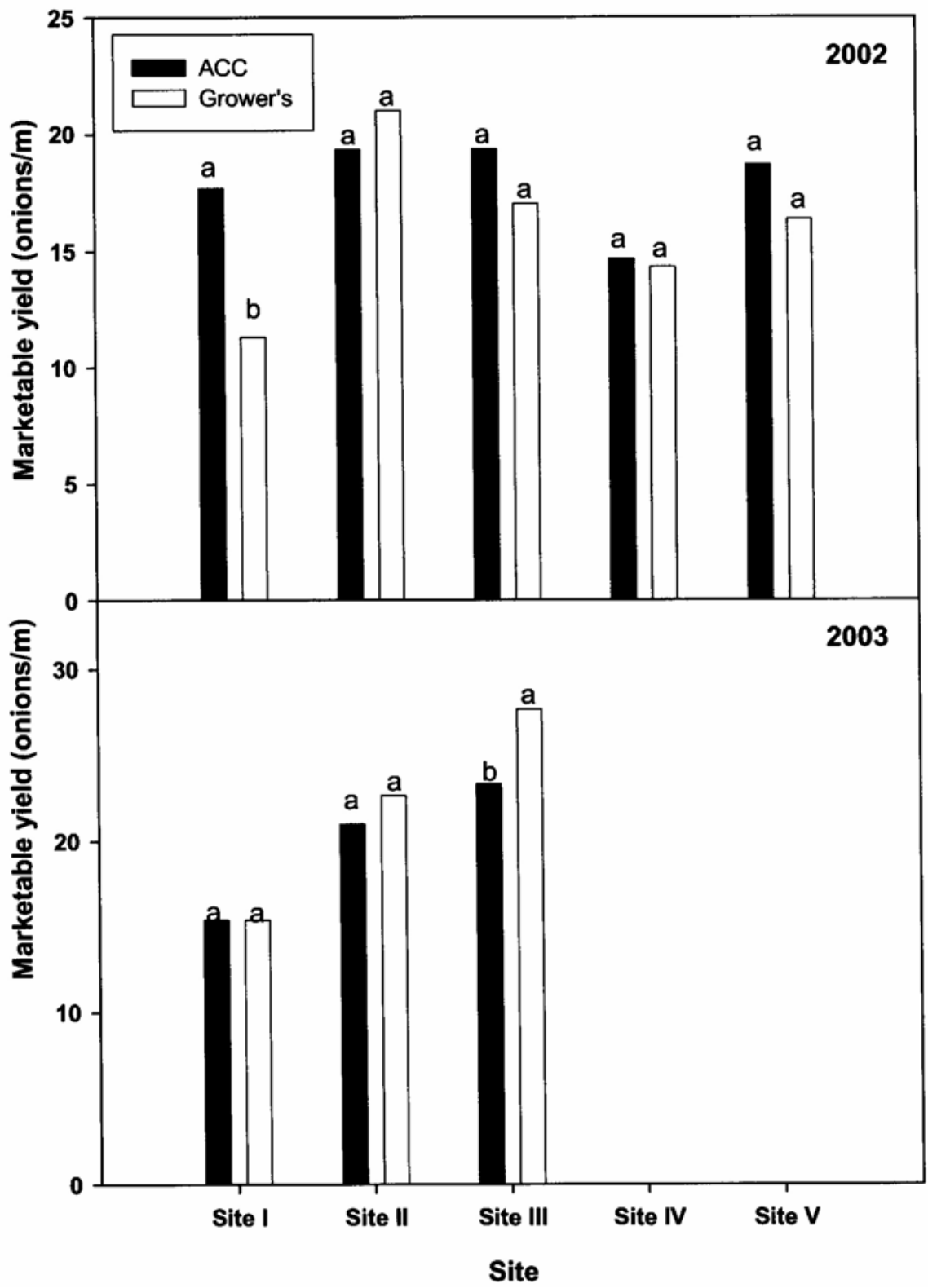

Fig. 7. Marketable yield (onions $\mathrm{m}^{-1}$ of row) in the sections of the fields sprayed according to the grower's schedule (light bars) and sprayed when airborne conidium concentration (ACC) reached 10 to 15 conidia $\mathrm{m}^{-3}$ (dark bars). Bars with the same letters are not significantly different according to the least significant difference test $(P=0.05)$. applied to the plots sprayed according to the grower's conventional schedules (Table 2; Fig 5). In 2003, the epidemic of Botrytis leaf blight was severe at site I, where ACC reached the threshold of 10 to 15 conidia $\mathrm{m}^{-3}$ on 5 June. On 3 July, ACC reached 47 conidia $\mathrm{m}^{-3}$, which was shortly followed by an increase in the number of lesions on the lower leaf from less than 1 to $3.2 \mathrm{LL}$ (Fig. 6). Again, toward the end of the season, ACC exceeded the threshold, reaching 120 and 158 conidia $\mathrm{m}^{-3}$ on 7 and $8 \mathrm{Au}-$ gust, and the number of lesions on the lower leaf reached $35 \mathrm{LL}$ on 12 August. At site II, both ACC and number of lesions remained below the threshold except on 9 August, where it was 35 conidia ${ }^{-3}$ (Fig. 6). At site III, the ACC remained below the threshold until 5 August; however, the number of lesions on the lower leaf ranged from 1 to 8 for most of the season. Nevertheless, fewer fungicide sprays were applied to plots sprayed according to the ACC schedule than to conventionally sprayed plots: a total of 10 compared with 23 for the three sites (Table 2). With the exception of site I in 2002 and site III in 2003 , there was no significant difference in marketable yield from plots sprayed according to the ACC schedule and those sprayed according to the grower's schedules (Fig. 7). For site I in 2002, marketable yield was significantly lower in the grower's schedule plot and, at site III in 2003, it was significantly higher; however, only four sprays were used in the ACC schedule plot compared with nine applied to the conventionally sprayed plot.

\section{DISCUSSION}

The control of Botrytis leaf blight is essential to achieve commercially acceptable onion crop yields. Although the disease can be controlled by regular application of fungicide sprays, these are not needed if environmental conditions are unfavorable for disease development or if inoculum is absent or present only in small amounts $(19,26)$. Monitoring disease levels (19) has been used to start fungicide programs and has been proven to be successful $(2,26)$. However, lesions of $B$. squamosa can be difficult to detect at the initial stages of disease development and can be easily confused with insect or soil particle damage. It has been shown that airborne inoculum plays a vital role in the development of epidemics cause by B. squamosa. Sutton et al. (23) reported a good correlation between ACC and severity of leaf dieback caused by B. squamosa. Vincelli and Lorbeer (27) reported that, in onion crops, with some exceptions, days with more than 10 conidia $\mathrm{m}^{-3}$ were associated with large increases in Botrytis leaf blight severity. Based on this finding, they developed a model for forecasting the sporulation of $B$. squamosa based on weather data. In the present study, we evaluated the potential of using airborne inoculum measurements as 
an aid for improving Botrytis leaf blight management in onion crops. Our results suggest that postponing the start of a regular fungicide spray program until a threshold of 10 to 15 conidia $\mathrm{m}^{-3}$ is reached can help reduce fungicide use. Using this criteria, combined with critical disease measurements to help choose the fungicide used, reduced the amount of fungicide used by 56 to $75 \%$ compared with a conventional spray program.

Although the importance of airborne inoculum has been recognized in the development of many polycyclic disease epidemics (indeed, the presence of inoculum is one of the elements in the disease triangle; 29), its use in practice has been limited because of the difficulties in quantifying it. Consequently, forecasting systems have been developed to estimate inoculum production or potential from weather measurements: for example, for Botrytis leaf blight (28) and apple scab caused by Venturia inaequalis (11). Although such systems are predictive and require only weather data, this may be available only at a regional scale, limiting its "on-farm" use. In addition, they estimate only the potential for inoculum occurrence, not its actual presence. Spore samplers, such as those used in these experiments, can be inexpensive and relatively easy to use by extension service workers or as part of a scouting system. They can be installed directly in the field or as part of a regional network. However, with these samplers, examination of collection surfaces is required to obtain spore counts accurate enough to estimate if the threshold is reached, and this requires significant amounts of time (approximately $15 \mathrm{~min}$ per rod) and expertise. This can make it difficult to use the results in "real time." These limitations could be overcome by adopting new methods for quantifying airborne spores based on immunological (14) or molecular techniques $(4,10,16)$. Such techniques could result in standardized and rapid methods of spore quantification, making inoculum detection a more practical tool in disease management.

The adoption of an improved spray decision strategy based on inoculum monitoring could, in the long term, reduce the amount of fungicide used, although fungicide use may not be reduced in years of high disease pressure. This, in turn, should reduce the potential for development of fungicide resistance in $B$. squamosa populations. Recently, resistance to iprodione was detected in $11 \%$ of the isolates of $B$. squamosa collected from the organic soil area southwest of Montreal (24). The economic benefits of such a disease management program will depend on the number and cost of fungicides saved and on cost of sampling, including purchase and mainte- nance of spore samplers and inoculum quantification. This may be prohibitive for individual growers; however, grower cooperatives, agricultural consultant groups, or extension services could implement such programs over a region or for a number of growers. For example, in the organic soil area southwest of Montreal, a large proportion of the onion growers are members of scouting programs that currently organize disease assessment measurements and have been involved in an air sampling pilot study.

In this study, the potential of inoculum measurement as an aid to manage Botrytis leaf blight was evaluated on a semicommercial scale. To be implemented on a larger scale, detailed information will be needed on the spatial distribution of airborne conidia to help determine the location and number of spore samplers required per field or per farm. Nevertheless, this study showed that inoculum quantification, in combination with conventional disease assessment, is potentially useful in the management of Botrytis leaf blight of onion.

\section{ACKNOWLEDGMENTS}

We thank D. Rolland, A. Lefebvre, M. Tremblay, J.-F. Desteredjian, N. Surdek, all the summer students, and the scouts from the PRISME consortium for their technical assistance and spore quantification.

\section{LITERATURE CITED}

1. Alderman, S. C., Biernbaum, J. A., Hoffhines, M., Timberlake, D. M., Welch, D. P., Lacy, M. L., and Barr, R. O. 1987. A simulation model of the spread of Botrytis leaf blight of onion and its effect on onion yields. Agric. Ecosyst. Environ. 19:55-70.

2. Boivin, G., and Sauriol, P. 1984. Dispersion statistics and sequential sampling plan for leaf blight caused by Botrytis squamosa in onions. Phytopathology 74:1385-1387.

3. Bugiani, R., Govoni, P., Bottazzi, R., Giannico, P., and Montini, B. 1995. Monitoring airborne concentration of sporangia of Phytophthora infestans in relation to tomato late blight in Emilia Romagna, Italy. Aerobiologia: 11:4146.

4. Calderon, C., Ward, E., Freeman, J., and McCartney, A. 2001. Detection of airborne fungal spores sampled by rotating-arm and Hirst-type spore traps using polymerase chain reaction. J. Aerosol Sci. 33:283-296.

5. Conseil des productions végétales du Québec (CPVQ). 1999. Légumes: Protection. Ministère de l'Agriculture, des pêcheries et de l'alimentation du Québec. Légumes agdex 250/1605.

6. Currah, L., and Maude, R. B., 1984. Laboratory tests for leaf resistance to Botrytis squamosa in onions. Ann. Appl. Biol. 105:277283

7. Dingley, J. M. 1961. New records of fungus disease in New Zealand. N. Z. J. Agric. Res 4:336.

8. Ellerbrock, L. A., and Lorbeer, J. W. 1977. Sources of primary inoculum of Botrytis squamosa. Phytopathology 67:363-372.

9. Ellerbrock, L. A., and Lorbeer, J. W. 1977. Survival of sclerotia and conidia and of Botrytis squamosa. Phytopathology 67:219-225.
10. Freeman, J., Ward, E, Cameron, C., and McCartney, A. 2002. A polymerase chain reaction (PCR) assay for the detection of inoculum of Sclerotinia sclerotiorum. Eur. J. Plant Pathol. 108:877-886.

11. Gadoury, D. M., and MacHardy, W. E. 1982. A model to estimate the maturity of ascospores of Venturia inaequalis. Phytopathology 72:901-904.

12. Hancock, J. G., and Lorbeer, J. W. 1963. Pathogenesis of Botrytis cinerea, B. squamosa, and $B$. allii on onion leaves. Phytopathology 53:669-673.

13. Hennebert, G. L. 1964. Botryotinia squamosa nouveau parasite de l'oignon en Belgique. Parasitica 20:138

14. Kennedy, R., Wakeham, A. J., Byrne, K. G., Meyer, U. M., and Dewey, F. M. 2000. A new method to monitor airborne inoculum of the fungal plant pathogens Mycosphaerella brassicicola and Botrytis cinerea. Appl. Environ. Microbiol. 66:2996-3000.

15. Lacy, M. L., and Pontius, G. A. 1983. Prediction of weather-mediated release of conidia of Botrytis squamosa from onion leaves in the fields. Phytopathology 73:670-676.

16. McCartney, H. A, Foster S. J., Fraaije B. A., and Ward, E. 2003. Molecular diagnostics for fungal plant pathogens. Pest Manage. Sci. 59:129-142.

17. Page, O. T. 1953. Botrytis spot of onion leaves in Ontario. Plant Dis. Surv. 37:513.

18. Ramsey, G. R., and Lorbeer, J. W. 1986. The role of temperature and moisture in onion flower blight. Phytopathology 76:612.

19. Shoemaker, P. B., and Lorbeer, J. W., 1977 Timing initial fungicide application to control Botrytis leaf blight epidemics on onions. Phytopathology 67:409-414

20. Steel, R. G. D., and Torrie, J. H., 1980. Principles and Procedures of Statistics, a Miometrical Approach, 2nd ed. McGraw-Hill Book Company, New York.

21. Sutton, J. C., James, T. D. W., and Rowell, P. M. 1983. Relation of weather and host factors to an epidemic of Botrytis leaf blight in onions. Can. J. Plant Pathol. 5:256-265.

22. Sutton, J. C., James, T. D. W., and Rowell, P. M., 1986. BOTCAST: a forecasting system to time the initial fungicide sprays for managing Botrytis leaf blight of onions. Agric. Ecosyst. Environ. 18:123-143.

23. Sutton, J. C., Swanton, C. J., and Gillespie, T. J. 1978. Relation of weather variables and host factors to incidence of airborne spores of $\mathrm{BO}$ trytis squamosa. Can. J. Bot. 56:2460-2469.

24. Tremblay, M., Talbot, B. G., and Carisse. O. 2003. Sensitivity to different classes of fungicides in Botrytis squamosa. Plant Dis. 87:573578.

25. Viennot-Bourgin, G., 1952. Sur la présence en France de Botrytis squamosa, parasite de l'oignon. Rev. Pathol. Vég. Entomol. Agric. 31:82.

26. Vincelli, P. C., and Lorbeer, J. W. 1987. Sequential sampling plan for timing initial fungicide application to control Botrytis leaf blight of onion. Phytopathology 77:1301-1303.

27. Vincelli, P. C., and Lorbeer, J. W. 1988. Relationship of precipitation probability to infection potential of Botrytis squamosa on onion Phytopathology 78:1078-1982.

28. Vincelli, P. C., and Lorbeer, J. W. 1989. BLIGHT-ALERT: a weather-based predictive system for timing fungicide applications on onion before infection periods of Botrytis squamosa. Phytopathology 79:493-498.

29. Zadoks, J. C., and Schein, R. D. 1979. Epidemiology and Plant Disease Management. Oxford University Press, Inc., New York. 